\title{
POTENTIAL USES OF OIL PALM (Elaeis guineensis) LEAF EXTRACT IN TOPICAL APPLICATION
}

\section{NOR ZULIANA YUSOF*; SITI SALWA ABD GANI**; YASMEEN SIDDIQUI;; NOR FADZILLAH MOHD MOKHTAR ${ }^{\ddagger}$ and ZAFARIZAL ALDRIN AZIZUL HASAN*}

\begin{abstract}
The antioxidant, anti-microbial activity and potential application of oil palm (Elaeis guineensis) leaf extract (OPLE) as a skin lightening and sunscreen agent in topical application were evaluated. Currently, there are no evidence of skin lightening effect and protection against ultraviolet (UV) irradiation of OPLE. OPLE contains $9.84 \pm 0.06 \mathrm{mg}$ gallic acid equivalent per gram of dry extract and shows antioxidant activity through 2,2-diphenyl-1-picrylhydrazyl assay with $\mathrm{IC}_{50}$ of $247 \pm 0.58 \mu \mathrm{g} \mathrm{ml} \mathrm{m}^{-1}$. OPLE was effective only against gram-positive bacteria and the minimum inhibitory concentration was $12.5 \mathrm{mg} \mathrm{ml}^{-1}$. OPLE also inhibited mushroom tyrosinase enzyme with $\mathrm{IC}_{50} 254.88 \mu \mathrm{g} \mathrm{ml}^{-1}$. Determination of $U V$ spectrophotometric and in vitro sun protection factor (SPF) indicated that OPLE provides a protection against ultraviolet $B$ (UVB) and ultraviolet A (UVA) irradiation. OPLE were mixed with glycerine at 1\%,5\% and 10\% concentrations and showed slightly increase in SPF values from $0.96,1.48$ and 1.87, respectively. The UVA/UVB ratios were significantly increase from 0.076 for glycerine to $0.645,0.906$ and 0.910 for OPLE at 1\%, 5\% and $10 \%$ in glycerine, respectively. OPLE showed potentially good UV absorbance at UVB and UVA range wavelength and can be used as natural sunscreen and skin lightening agent for topical application.
\end{abstract}

Keywords: oil palm leaf extract, antioxidant, anti-microbial, anti-tyrosinase, ultraviolet radiation

Date received: 20 April 2016; Sent for revision: 26 April 2016; Received in final form: 28 August 2016; Accepted: 1 September 2016.

\section{INTRODUCTION}

Malaysia is one of the largest producers and exporters of palm oil and its products in the world. In 2015, the total planted area has reached to 5.64

* Malaysian Palm Oil Board, 6 Persiaran Institusi Bandar Baru Bangi, 43000 Kajang,

Selangor, Malaysia.

E-mail: zuliana@mpob.gov.my

** Halal Products Research Institute, Universiti Putra Malaysia, Putra Infoport, 43400 UPM Serdang, Selangor, Malaysia.

‡ Laboratory for Food Crops, Institute of Tropical Agriculture, Universiti Putra Malaysia,

43400 UPM Serdang, Selangor, Malaysia.

\# Department of Mathematics, Universiti Putra Malaysia, 43400 UPM Serdang, Selangor, Malaysia. million hectares, an increase of $4.6 \%$ against 5.39 million hectares recorded in the previous year, 2014 (MPOB, 2015). Apart from palm oil production, oil palm industries yield several by-products such as oil palm trunk, oil palm fronds, empty fruit bunches, palm kernel cake, palm oil mill effluent and palm pressed fibre (Abdullah and Sulaiman, 2013). Several of these by-products are utilised in generating compost and fertilisers. However, the process is time-consuming. The major contribution of the oil palm waste in Malaysia is derived from the oil palm fronds (Basiron and Chan, 2004). Normally, oil palm fronds are left rotting between the rows of palm trees, mainly for soil conservation and long-term benefit of nutrient recycling. Oil palm fronds also can be used as ingredients for livestock 
feeding (Wan Zahari et al., 2002; Wan Zahari and Mohd Farid, 2011). In addition, palm leaves are abundant and are under-utilised. Several studies have reported that oil palm leaf extract (OPLE) are rich in antioxidant activity ( $\mathrm{Ng}$ and Choo, 2010; Jaffri et al., 2011; Vijayarathna and Sasidharan, 2012). In addition, the antioxidative activities are higher in the dried leaves extract compared to wet leaves extract (Ng and Choo, 2010).

Numerous studies were carried out to characterise the chemical compositions of OPLE. It largely consists of phenolic compounds such as glycosylated flavonoids, catechins, (-)-catechin gallate, ferulic acid, gallic acid, protocatechuic acid and carotenoids (Runnie et al., 2003; Phang et al., 2009).

Phenolic compounds are the most common water-soluble antioxidant (Macheix et al., 1990) and have anti-microbial properties (Jurd et al., 1971). Sato and Toriyama (2009) reported that catechin group has anti-melanogenic agent properties and that it might be effective in hyperpigmentation disorders. Therefore, the total phenolic content, antioxidant, anti-microbial properties and the effect of OPLE on inhibition of tyrosinase enzyme through in vitro tyrosinase assay were determined in this study.

The ultraviolet (UV) radiation is the waveband that affects skin pigmentation and can be divided into three main wavelengths i.e., UVC (200-290 $\mathrm{nm})$, UVB (290-320 nm) and UVA (320-400 nm). UVA is further subdivided into UVA II (320-340 nm) and UVA I (340-400 nm) (ISO 24444:2010). UVB contributes for about $5 \%$ while UVA for about 95\% of the ultraviolet spectrum and both UVB and UVA can penetrate the ozone layer (Maria et al., 2012). UVB will penetrate the epidermis, but it is mostly absorbed just above the dermis. On the other hand, UVA radiation penetrates deeper in the skin, reaching the dermis (Dupont et al., 2013). Exposure to UVA radiation results in damage to the elastic and collagen fibres of the connective tissue of the skin, which causes premature ageing, while UVB radiation induces acute inflammation or sunburn and intensification of photo-ageing (United States Environmental Protection Agency, 2010).

There are two main types of active ingredients used in sun care formulations to control the amount of UV light penetrating the skin: chemical (organic) sunscreens and physical (inorganic) sunscreens. Chemical sunscreens are incorporated in skin care products to absorb the UV light. Although they are effective UV filters, several UV filters were shown to trigger skin allergic reactions when applied onto the skin (Collaris and Frank, 2008). On the other hand, physical sunscreens such as titanium dioxide $\left(\mathrm{TiO}_{2}\right)$ and zinc oxide $(\mathrm{ZnO})$ work by reflecting and scattering the UV light. Disadvantages of these inorganic sunscreens are their unappealing visual appearance because of the solid consistency that leave unpleasant white marks onto the skin when high quantities are incorporated into sunscreen products (Anderson et al., 1997).

The application of sunscreens is an efficient method of protecting the skin against UV radiations. The efficacy of sunscreens is characterised by the sun protection factor (SPF), a ratio calculated from the energies required to induce a minimum erythema response with and without sun product applied to the skin of human volunteers, using UV radiation usually from an artificial source. The SPF is a numerical rating system to indicate the degree of protection provided by sun care products like sunscreen (COLIPA, 2006).

Determination of SPF can be carried out through in vivo and in vitro methods. Due to the high costs and time-consuming of in vivo SPF determination, the in vitro SPF test method is the preferred test (Maria et al., 2012). At present, there are three in vitro methods for evaluation of protection from UVA, namely from the United States (Food and Drug Administration-FDA), European Union (Cosmetics Europe - The Personal Care Association - COLIPA) and United Kingdom (Beauty Health Pharmacy and Prescriptions -Boots) (Maria et al., 2012). The Boots star rating system (Boots the Chemist Ltd, 1992) and critical wavelength (Diffey, 1994) were used to measures the protection against UVA.

Recently, the use of natural sunscreen has been gaining significant attention due to its safety, multiple biological actions on skin and cost effectiveness. The plant actives are preferred over chemical sunscreen due to the broad spectrum of UV absorption, protection against oxidative stress, inflammation and cancer (Anitha, 2012; Goswami et al., 2013; Korac and Khambholja, 2011).

Based on the literature search carried out, no specific reports have been published on the protection against UV irradiation of phenolic compounds derived from OPLE. In this study, in vitro SPF and UVA/UVB ratio were used to investigate the effects of OPLE on protection against UVB and UVA irradiation. This will eventually lead to development of oil palm (Elaeis guineensis) leaf extract as an active ingredient for topical application.

\section{MATERIALS AND METHODS}

\section{Chemical Material}

The reagents Folin-Ciocalteu's phenol reagent, gallic acid, 2,2-Diphenyl-1-picrylhydrazyl (DPPH), 6-Hyroxy-2,5,7,8-Tetramethylchroman-2-Carboxylic acid (TROLOX), 3,4-dihyroxy-L-phenylalanine (L-DOPA), lyophilised mushroom tyrosinase and kojic acid were purchased from Sigma-Aldrich, Steinheim, Germany. The remaining reagents were supplied by different companies, as follow: ethanol 
(Friedemann Schmidt, Parkwood WA, Australia), methanol and dimethylsulfoxide (DMSO) (Fisher Chemical, Loughborough, United Kingdom), sodium carbonate anhydrous (R\&M Chemicals, Essex, United Kingdom), phosphate buffer solution (PBS) (Gibco by Life Technologies, New York, USA) and glycerine (Croda, Seraya Avenue, Singapore). All reagents and solvents were of analytical grade. ABS Green Tea Extract (GTE) was purchased from Active Concepts LLC, North Carolina, USA and used as a benchmark in determination of antityrosinase activity and in vitro SPF.

\section{Biological Material}

The Mueller-Hinton agar was obtained from Oxoid (UK). Sabaroud dextrose agar, MuellerHinton broth and potato dextrose broth were purchased from Difco (USA). American Type Culture Collection (ATCC) bacterial strains were used; Staphylococcus aureus ATCC 6538, Pseudomonas aeruginosa ATCC 15442 and Escherichia coli ATCC 8739.

\section{Preparation of Oil Palm Leaf Extract}

Fresh oil palm (Elaeis guineensis) leaves from mature palm, aged 6 years were obtained from the Malaysian Palm Oil Board (MPOB), Bangi, Selangor, Malaysia. Three batches of oil palm leaves were collected from different oil palm fronds (OPF) of different trees. The sampling was performed from the middle part of OPF, followed by the middle part of oil palm leaves. The leaves collected were washed with tap water and chopped coarsely and left to dry in the oven at $40^{\circ} \mathrm{C}$ for $24 \mathrm{hr}$. The dried leaves were ground to powder using a mechanical blender and $20 \mathrm{~g}$ of the leaf powder were extracted with absolute ethanol at a 1:10 (w/v) under soxhlet extractor for 2 $\mathrm{hr}$ at $78.0^{\circ} \mathrm{C}$. The extracts were then filtered through filter paper (Whatmann No. 1) and vacuum-dried in a rotary evaporator (Premium 7 , Heidolph) at $40^{\circ} \mathrm{C}$, until the solvent was completely removed or onetenth its volume to yield dark green waxy material.

\section{Determination of Total Phenolics}

Total phenolic compounds in the crude ethanolic extract OPLE were determined using the Folin-Ciocalteau method (Singleton et al., 1999). In brief, $0.1 \mathrm{ml}$ of ethanolic OPLE solution (1:10, $\mathrm{w} / \mathrm{v}$ ) was added to $0.5 \mathrm{ml}$ Folin-Ciocalteau reagent, followed by $7 \mathrm{ml}$ distilled water. The mixture was left standing at room temperature, in the dark for 5 min. Then, $1.5 \mathrm{ml}$ sodium carbonate $\left(15 \% \mathrm{Na}_{2} \mathrm{CO}_{3} /\right.$ $\mathrm{H}_{2} \mathrm{O}$ ) solution was added and the mixture was left at room temperature for another $2 \mathrm{hr}$. UV absorbance at $765 \mathrm{~nm}$ was measured using microplate reader spectrophotometer (Synergy H1, BioTek, USA).
Samples were measured in three replicates. Gallic acid was used as reference. Standard curve of gallic acid solution (0, 10, 20, 40, 60, 80 and 100 ppm) was prepared using the similar procedure. The results were expressed as $\mathrm{mg}$ gallic acid equivalent (GAE) $\mathrm{g}^{-1}$ of extract.

$$
\mathrm{T}=\mathrm{C} \times \mathrm{V} / \mathrm{M} \quad \text { Equation (1) }
$$

where $T$ is the total phenolic content in $\mathrm{mg} \mathrm{g}^{-1}$ of the extract as GAE;

$C$ is the concentration of gallic acid established from the calibration curve in $\mathrm{mg} \mathrm{ml}^{-1}$;

$V$ is the volume of the extract solution in $\mathrm{ml}$; and $M$ is the weight of the extracts in grams.

\section{DPPH Radical Scavenging Activity}

The DPPH free radical scavenging activity of OPLE was determined according to the method described by Blois (1958) with slight modifications. Briefly, $4.2 \mathrm{mg}$ of DPPH powder was dissolved in $50 \mathrm{ml}$ of methanol $(0.2 \mathrm{mM})$. Then, $50 \mu \mathrm{l}$ OPLE at different concentrations of 62.5, 125, 250 and 500 $\mu \mathrm{g} \mathrm{ml} \mathrm{m}^{-1}$ in methanol were prepared and reacted with $195 \mu 1$ of DPPH methanolic solution in 96well microtitre plate. After $60 \mathrm{~min}$ of incubation, the absorbance values of the samples were read at $540 \mathrm{~nm}$ using a microplate reader (Synergy H1, BioTek, USA). Trolox was used as the standard. The absorbance of the DPPH and methanol was used as a negative control. The analysis was done in triplicate to confirm the reproducibility of the data. The antioxidant activity, expressed as the percentage of $\mathrm{DPPH}$ radical scavenging, was calculated by using Equation (2).

$$
\begin{aligned}
& \% \mathrm{DPPH} \text { scavenging activity }= \\
& \frac{\left[\mathrm{Abs}_{\text {negative control }}-\mathrm{Abs}_{\text {sample/standard }}\right]}{\mathrm{Abs}_{\text {negative }} \text { control }} \times 100 \text { Equation (2) }
\end{aligned}
$$

The $\mathrm{IC}_{50}$ of DPPH assay represents the concentration of the tested sample needed to reduce the DPPH by $50 \%$ where the value obtained from linear regression graph.

\section{Determination of Anti-tyrosinase Activity}

The anti-tyrosinase activity of OPLE was evaluated based on inhibition of mushroom tyrosinase by the test sample with L-DOPA as substrate using a method described by Chiari et al. (2010). The test solution was serially diluted twofold from $500 \mu \mathrm{g} \mathrm{ml}^{-1}$ using DMSO and $20 \mu \mathrm{l}$ was pipetted into a 96-well plate, followed by addition of $138 \mu 1$ phosphate buffer solution and $2 \mu 1$ mushroom tyrosinase solution (2500 $\mathrm{U} \mathrm{ml}^{-1}$, in PBS). After incubation at $37^{\circ} \mathrm{C}$ for $90 \mathrm{~min}, 40 \mu \mathrm{l}$ of L-DOPA $(2.5$ 
mM in PBS) was added, and measurement at $450 \mathrm{~nm}$ monitored for $20 \mathrm{~min}$. Commercial GTE was used as a benchmark active for comparison purposes and kojic acid was used as a standard positive control. The tyrosinase inhibitory activities of the tested samples were expressed as $\mathrm{IC}_{50}$ values which are the concentration required inhibiting $50 \%$ of tyrosinase activity.

\section{Anti-microbial Activity Assays}

The minimum inhibitory concentrations (MIC) of plant extracts were determined using the broth microdilution method in 96-well plates as described by Eloff (1998). The MIC was tested on Staphylococcus aureus, Pseudomonas aeruginosa and Escherichia coli. The OPLE were dissolved in 10\% DMSO at 100, 50, $25,125,6.25,3.13,1.56,0.78$ and $0.39 \mathrm{mg} \mathrm{ml}^{-1}$. The bacteria were cultured in Mueller-Hinton (MH) broth for $24 \mathrm{hr}$. Streptomycin disc $(10 \mu \mathrm{g})$ was used as the positive control whereas broth, $10 \%$ DMSO and water were used as negative controls. In brief, $100 \mu 1$ of water and $100 \mu 1$ of test samples were added in each well. The optical density of $S$. aureus, $P$. aeruginosa and $E$. coli were adjusted with $\mathrm{MH}$ broth to match that McFarland standard, equivalent to $10^{8}$ colony forming units at $600 \mathrm{~nm}$. After that, $100 \mu \mathrm{l}$ of the adjusted culture were added to all the wells. The microtitre plates were then incubated for $24 \mathrm{hr}$ at $37^{\circ} \mathrm{C}$ and the results were observed. The clear wells were considered as the MIC values.

Minimum bactericidal concentration (MBC) was determined by pipetting $100 \mu \mathrm{l}$ of bacterial cells from the MIC test plate onto $\mathrm{MH}$ agar and spread on the surface of the agar. The plates were then incubated at $37^{\circ} \mathrm{C}$ for $24 \mathrm{hr}$. Colony of each bacteria at $100,50,25,125,6.25,3.13,1.56,0.78$ and $0.39 \mathrm{mg}$ $\mathrm{ml}^{-1}$ in $10 \%$ DMSO were observed and the lowest concentration of sample required to kill $99.9 \%$ the tested microorganism was recorded as MBC.

\section{Determination of in vitro Sun Protection Factor}

The determinations of in vitro sun protection factor (SPF) for UVB and UVA of all samples were performed by Labsphere UV-2000S Ultraviolet Transmittance Analyser using polymethyl methacrylate plate with 6 micron roughness and 1.30 $\mathrm{mg} \mathrm{cm}-2$ of product application (COLIPA, 2011). The in vitro technique involves measuring the spectral transmittance at UV wavelengths from $280 \mathrm{~nm}$ to $400 \mathrm{~nm}$ and the data are used to determine the SPF. Physical measurements have shown that the solar erythemal response is inversely proportional to the radiation wavelength. The shorter wavelength or UVB region at $280-315 \mathrm{~nm}$ can induce erythemal reaction. No erythemal reaction is observed for the UVA region at 315 - $400 \mathrm{~nm}$ (Diffey and Robson, 1989).
SPF is defined as the ratio of the minimal erythema dose (MED) with applied sunscreen and the MED without sunscreen (COLIPA, 2006). The SPF is an indicator of protection against UVB radiation and is calculated based on Equation (3):

$$
\mathrm{SPF}_{\text {in vitro }}=\frac{\int_{290 \mathrm{~nm}}^{400 \mathrm{~nm}} \mathrm{E}(\lambda) \cdot \mathrm{S}(\lambda) \cdot d \lambda}{\int_{290 \mathrm{~nm}}^{400 \mathrm{~nm}} \mathrm{E}(\lambda) \bullet \mathrm{S}(\lambda) \bullet \mathrm{T}(\lambda) \bullet d \lambda} \quad \text { Equation (3) }
$$

where, $E(\lambda)=$ erythema action spectrum, $S(\lambda)=$ solar spectral irradiance, $T(\lambda)=$ spectral transmittance of the sample.

The equation shows that the higher the amount of transmittance, the lower the SPF value. The transmittance spectrum of a sunscreen in either region is averaged in order to produce one value, which describes the amount of UVA or UVB blocking. The average transmittance in each region is given by Equations (4) and (5), respectively:

$$
\mathrm{T}(\text { UVA) })_{\mathrm{av}}=\frac{\sum_{315 \mathrm{~nm}}^{400 \mathrm{~nm}} \mathrm{~T} \lambda \cdot \times \Delta \lambda}{\sum_{315 \mathrm{~nm}}^{400 \mathrm{~m}} \Delta \lambda} \quad \text { Equation (4) }
$$

$$
\mathrm{T}(\mathrm{UVA})_{\mathrm{av}}=\frac{\sum_{280 \mathrm{~nm}}^{315 \mathrm{~nm}} \mathrm{~T} \lambda \cdot \times \Delta \lambda}{\sum_{280 \mathrm{~nm}}^{315 \mathrm{~nm}} \Delta \lambda} \quad \text { Equation (5) }
$$

where, $\Delta \lambda=$ measured wavelength interval Consequently, the percent blocking for UVA and $\mathrm{UVB}$, respectively, is calculated as in Equation (6);

$$
100 \%-\mathrm{T}(\mathrm{UVA})_{\mathrm{av}} \text { or } 100 \%-\mathrm{T}(\mathrm{UVB})_{\mathrm{av}} \text { Equation (6) }
$$

where, $\mathrm{T}(\mathrm{UVA})$ av or $\mathrm{T}(\mathrm{UVB}) \mathrm{av}$ is expressed as a percentage.

\section{Determination of UVA/UVB Ratio}

In addition to its ability to determine the SPF of a sunscreen, the in vitro technique can also measure the UVA protection of the sunscreen.

The spectral transmittance values, $\mathrm{T} \lambda$, are converted to spectral absorbance values $\mathrm{A} \lambda=-\log$ $(\mathrm{T} \lambda)$. A term called the UVA/UVB ratio is calculated, which is the ratio of the total absorption in the UVA to that in the UVB as in Equation (7):

$\frac{\mathrm{aUVA}}{\mathrm{aUVA}}=\frac{\int_{320 \mathrm{~nm}}^{400 \mathrm{~nm}} \mathrm{E}(\lambda) \cdot S(\lambda) \bullet d \lambda}{\int_{290 \mathrm{~nm}}^{320 \mathrm{~nm}} \mathrm{~A}(\lambda) \bullet \mathrm{d} \lambda}$ 
The star rating for UVA protection is determined from the measured UVA ratio as shown in the Table 1 (Boots the Chemists Ltd, 1992).

\section{Statistical Analysis}

All experiments were carried out in triplicate. The results are given as mean and standard deviation. Statistical analysis, analysis of variance (ANOVA) and Tukey tests, were carried out when necessary. The level of significance is 95\% $(\mathrm{p}<0.05)$.

\section{RESULTS AND DISCUSSION}

\section{Total Phenolic Content and DPPH Radical Cavenging Activity}

In brief, $20 \mathrm{~g}$ of the dried leaves were extracted using ethanol and the final dried extract weight was $2 \mathrm{~g}$. Therefore, the extraction yield of OPLE was $10 \%$. Figure 1 depicts the standard curve for the total phenolic content assay, whereby it demonstrated that as the concentration of gallic acid increased, the absorption also increased. It was observed that the reduction of Folin Ciocalteu reagent by phenolic ion will change its solution colour from yellow to blue (Prior et al., 2005). The graph produce a good correlation $\left(\mathrm{R}^{2}=0.9934\right)$ between concentration and its absorption spectrophotometrically at $765 \mathrm{~nm}$ and the equation for this graph: $y=0.0017 x+0.0068$ was used to calculate GAE of OPLE. From this study, OPLE contains $9.84 \pm 0.06 \mathrm{mg}^{\mathrm{GAE}} \mathrm{g}^{-1}$ of extract. Previous study reported that total phenolic content of dried OPLE was $10.2 \mathrm{mg} \mathrm{GAE} \mathrm{g}^{-1}$ ( $\mathrm{Ng}$ and Choo, 2010) and 70.07 $\pm 1.501 \mathrm{mg} \mathrm{GAE} \mathrm{g}^{-1}$ (Ng et al., 2013). The extraction using more polar solvents such as methanol resulted in a higher amount of total phenolic content with $24.3 \mathrm{mg} \mathrm{GAE} \mathrm{g}^{-1}$ as compared to green tea (22.5 $\mathrm{mg} \mathrm{GAE} \mathrm{g}^{-1}$ ) (Runnie et al., 2003).

Results shown in Table 2 and Figure 2 demonstrate the antioxidant activity of OPLE through DPPH scavenging assay from 62.5, 125, 250 and $500 \mu \mathrm{g} \mathrm{ml}^{-1}$ of concentration. The standard curve demonstrated a good correlation, as the concentration of OPLE increased, the antioxidant activity also increased. OPLE at $500 \mu \mathrm{g} \mathrm{ml}^{-1}$ shows higher antioxidant activity, $94.36 \pm 0.29 \%$ with an $\mathrm{IC}_{50}$ value of $247.00 \pm 0.58 \mu \mathrm{g} \mathrm{ml}^{-1}$. In 2010, $\mathrm{Ng}$ and Choo reported that dried leaf extract showed antioxidant activities ranged from 56\%-93\% when determined by the DPPH assay. The $\mathrm{IC}_{50}$ value in this study is much lower than values reported by Vijayarathna and Sasidharan (2012) with $\mathrm{IC}_{50} 814 \mu \mathrm{g} \mathrm{ml}^{-1}$ and $\mathrm{Ng}$ et al. (2013) with $\mathrm{IC}_{50} 646 \mu \mathrm{g} \mathrm{ml}^{-1}$. Lower $\mathrm{IC}_{50}$ value indicates higher antioxidant activity.

\section{Anti-bacterial Assays}

The anti-bacterial assay was carried out on gram positive bacteria $S$. aureus ATCC 6538, and two gram negative bacteria $P$. aeruginosa ATCC 15442 and E. coli ATCC 8739. A two-fold serially diluted OPLE concentrations were prepared at 100, 50, $25,12.5,6.25,3.13,1.56,0.78$ and $0.39 \mathrm{mg} \mathrm{ml}^{-1}$. The MIC result of OPLE against $S$. aureus ATCC 6538, P. aeruginosa ATCC 15442 and E. coli ATCC 8739 are presented in Table 3. The OPLE exhibits good anti-bacterial activity against $S$. aureus with lowest concentration that inhibited bacterial growth was $12.5 \mathrm{mg} \mathrm{ml}^{-1}$. The results were in accordance with the studies by Chong et al. (2008) and Vijayarathna et al. (2012) where the MIC values for the methanol extract of OPLE on $S$. aureus were $6.25 \mathrm{mg} \mathrm{ml}^{-1}$ and $12.5 \mathrm{mg} \mathrm{ml}^{-1}$, respectively. Gram negative bacteria, $P$. aeruginosa and $E$. coli were quite resistant to OPLE

TABLE 1. STAR RATING FOR ULTRAVIOLET (UVA) PROTECTION

\begin{tabular}{ccc}
\hline Mean UVA/UVB ratio & Star rating category & Category description \\
\hline 0.0 to 0.2 & - & Too low $/$ no claim \\
0.21 to 0.4 & $*$ & Minimum \\
0.41 to 0.6 & $* *$ & Moderate \\
0.61 to 0.8 & $* * *$ & Good \\
0.81 to 0.9 & $* * * *$ & Superior \\
0.91 and above & $* * * *$ & Ultra \\
\hline
\end{tabular}

TABLE 2. ANTIOXIDANT ACTIVITY OF OIL PALM LEAF EXTRACT (OPLE) ON SCAVENGING EFFECT USING DPPH ASSAY

\begin{tabular}{cccccc}
\hline \multirow{2}{*}{ Assay } & \multicolumn{4}{c}{ Concentration, $\mu \mathbf{g ~ m l}^{-1}$} & IC $_{50}, \boldsymbol{\mu g ~ m l}^{-1}$ \\
\cline { 2 - 5 } & $\mathbf{6 2 . 5}$ & $\mathbf{1 2 5}$ & $\mathbf{2 5 0}$ & $\mathbf{5 0 0}$ \\
\hline DPPH assay (\%) & $20.40 \pm 3.64$ & $30.65 \pm 0.41$ & $60.46 \pm 0.64$ & $94.36 \pm 0.29$ & $247.00 \pm 0.58$ \\
\hline
\end{tabular}

Note: DPPH - 2,2-Diphenyl-1-picrylhydrazyl. 


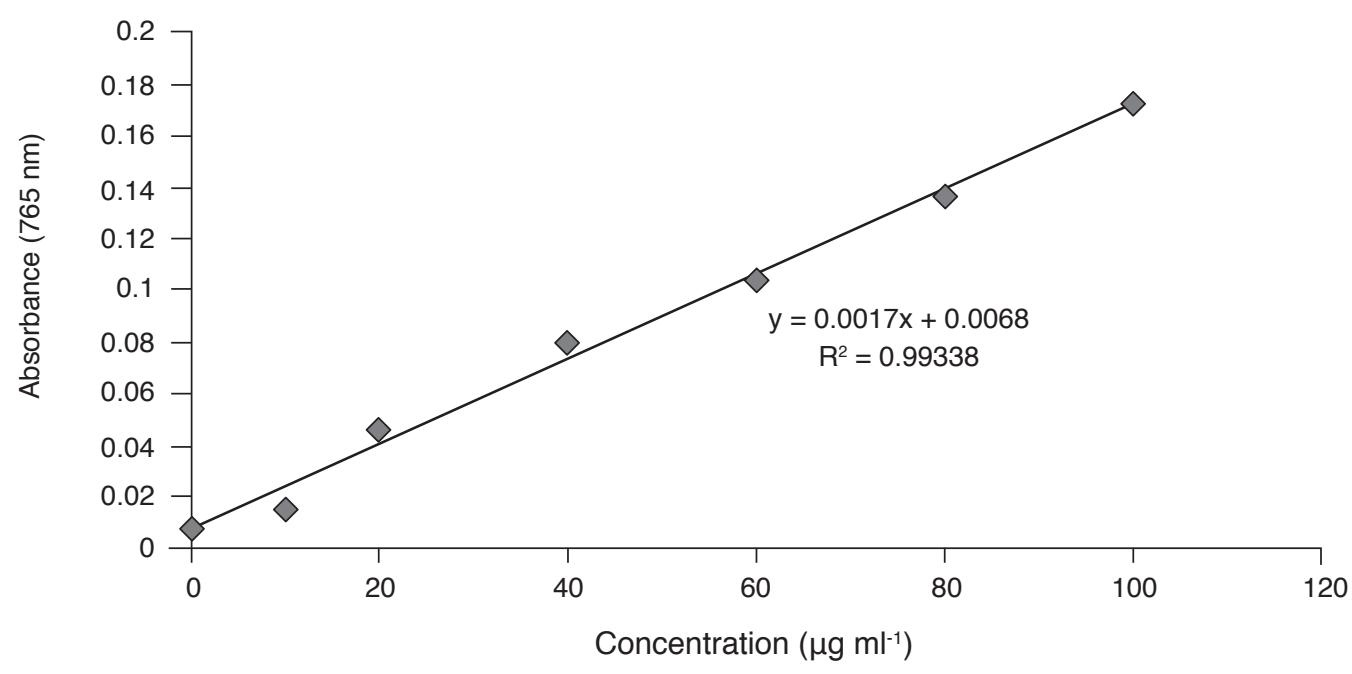

Figure 1. Folin Ciocalteu' gallic acid standard curve.

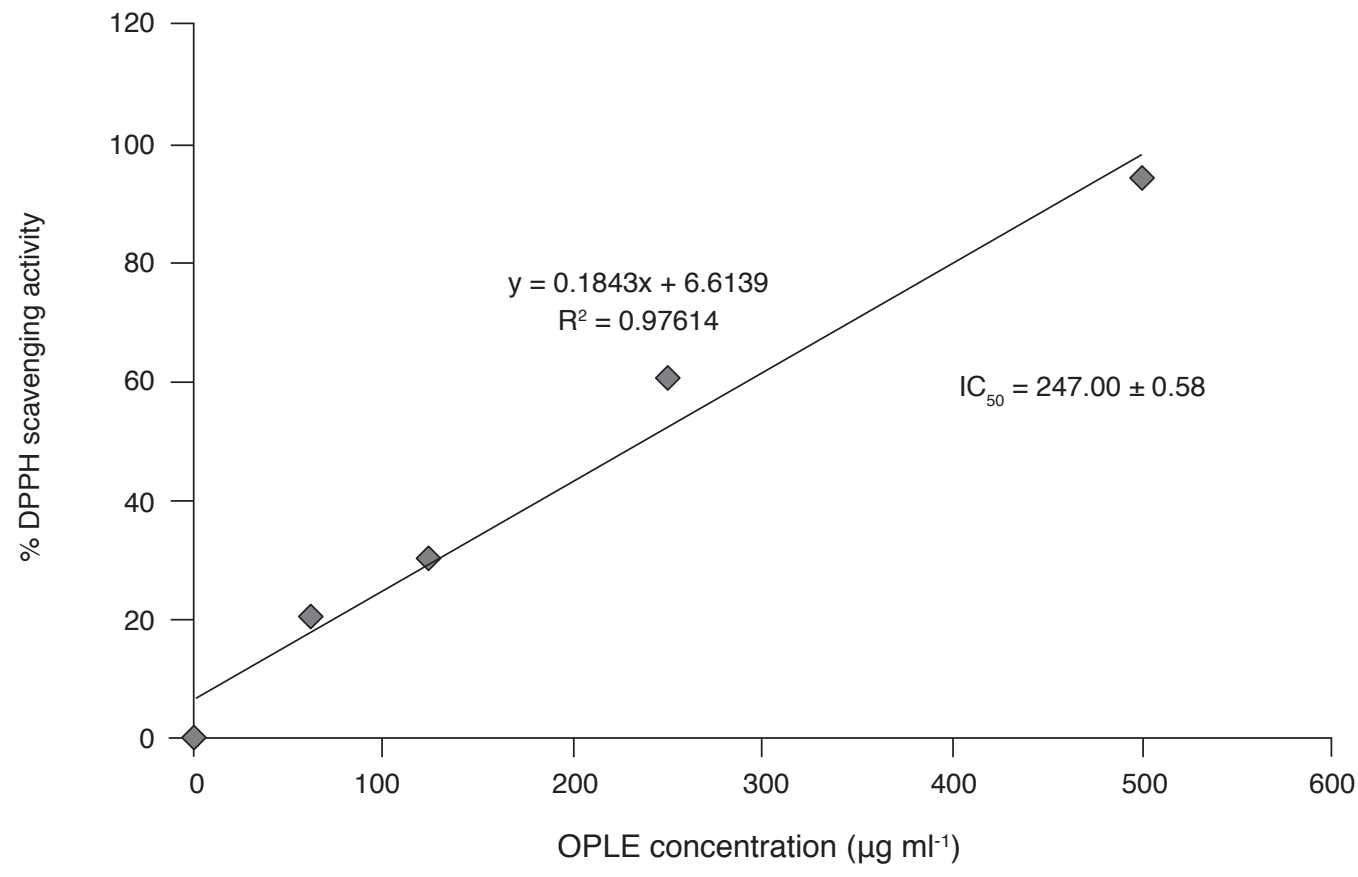

Figure 2. The 2, 2-Diphenyl-1-picrylhydrazyl (DPPH) radical scavenging activity (\%) of oil palm leaf extract (OPLE) ( $\left.\mu g \mathrm{ml}^{-1}\right)$.

TABLE 3. MINIMUM INHIBITORY CONCENTRATION (MIC) OF OPLE AGAINST DIFFERENT BACTERIA

\begin{tabular}{|c|c|c|c|c|c|c|c|c|c|}
\hline \multirow[t]{2}{*}{ Bacteria } & \multicolumn{9}{|c|}{ OPLE concentration $\left(\mathrm{mg} \mathrm{ml}^{-1}\right)$} \\
\hline & 100 & 50 & 25 & 12.5 & 6.25 & 3.13 & 1.56 & 0.78 & 0.39 \\
\hline \multicolumn{10}{|l|}{ Gram positive } \\
\hline Staphylococcus aureus ATCC 6538 & $\mathrm{C}$ & C & $\mathrm{C}$ & $\mathrm{C}$ & $\mathrm{NC}$ & $\mathrm{NC}$ & $\mathrm{NC}$ & $\mathrm{NC}$ & $\mathrm{NC}$ \\
\hline \multicolumn{10}{|l|}{ Gram negative } \\
\hline Pseudomonas aeruginosa ATCC 15442 & NC & $\mathrm{NC}$ & NC & $\mathrm{NC}$ & $\mathrm{NC}$ & NC & $\mathrm{NC}$ & $\mathrm{NC}$ & $\mathrm{NC}$ \\
\hline Escherichia coli ATCC 8739 & $\mathrm{NC}$ & $\mathrm{NC}$ & $\mathrm{NC}$ & $\mathrm{NC}$ & $\mathrm{NC}$ & $\mathrm{NC}$ & $\mathrm{NC}$ & $\mathrm{NC}$ & $\mathrm{NC}$ \\
\hline
\end{tabular}

Note: ${ }^{*} \mathrm{C}$ - clear (no bacterial growth), NC - not clear (bacterial growth). OPLE - oil palm leaf extract. 
and no inhibitory were recorded in this study. The results were supported by the finding from $\mathrm{Ng}$ et al. (2013) where methanolic extract from oil palm leaves showed anti-microbial activity with the exception to gram negative bacteria $E$. coli.

Results from the MBC assay supported the data obtained from the MIC determination assay where OPLE shows bactericidal activity towards $S$. aureus at $12.5 \mathrm{mg} \mathrm{ml}^{-1}$ and no inhibition were recorded for P. aeruginosa and E. coli (Figure 3). These results indicated that OPLE has anti-microbial activity against gram positive bacteria but no inhibition towards gram negative bacteria.

\section{Determination of Anti-tyrosinase Activity}

Skin pigmentation in human is caused by melanin synthesis in UV irradiated melanocytes. Upon exposure of the skin to UV radiation, melanogenesis is enhanced by the activation of the key enzyme of melanogenesis, tyrosinase (Gillbro and Olsson, 2011). Tyrosinase is a key enzyme in melanin synthesis that can catalyse three different reactions: the hydroxylation of tyrosine to DOPA, the oxidation of DOPA to DOPA quinone and the oxidation of 5,6-dihydroxyindole (DHI) to indole- quinone (Hearing and Tsukamoto, 1991). The capability of OPLE to inhibit tyrosinase activity can be translated to its potential as skin lightening agent. When tyrosinase enzyme activity is inhibited, melanin production is reduced, resulting in a fairer skin. Kojic acid, from mushrooms and other plant materials, is a common ingredient in skin lightening products. Green tea (Camellia sinensis L.) with major active constituents; epicatechin gallate, gallocatechin gallate, epigallocatechin gallate were reported to have stronger tyrosinase inhibitory activity (No et al., 1999; Jo et al., 2012) and therefore was used as a benchmark.

Figure 4 shows the anti-tyrosinase activity of OPLE, commercial GTE and kojic acid as a positive control. Anti-tyrosinase activity of kojic acid was significantly higher and gradually increased from $60.53 \%$ to $99.10 \%$ with an increment of concentration of test sample (Figure 4). The anti-tyrosinase activity of OPLE and commercial GTE ranged between $29.69 \%-64.62 \%$ and $48.36 \%-60.93 \%$, respectively. At highest concentration of $500 \mu \mathrm{g} \mathrm{ml}^{-1}$, the antityrosinase activity of OPLE and GTE were not significantly different with $p>0.05$. Therefore, OPLE exhibited an anti-tyrosinase activity as compared to GTE. Oil palm leaves were reported to have $8 \%$
Bacteria

Staphylococcus

aureus

ATCC 6538

Pseudomonas

aeruginosa

ATCC 15442

ATCC 15442

Escherichia coli ATCC 8739

\section{OPLE concentration (mg ml-1)}

50

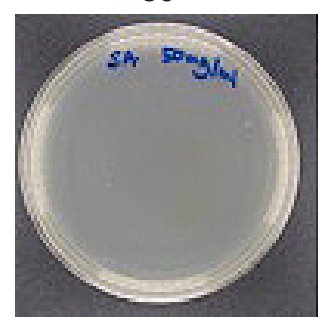

Negative

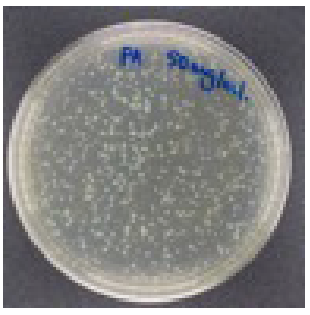

Positive

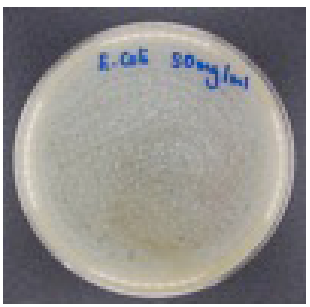

Positive
25

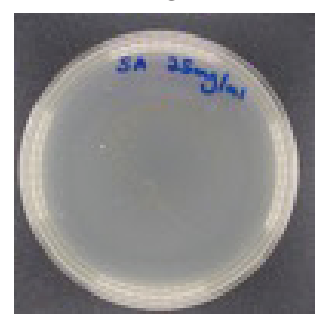

Negative

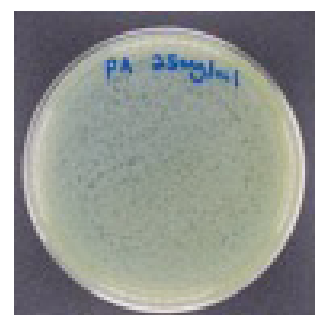

Positive

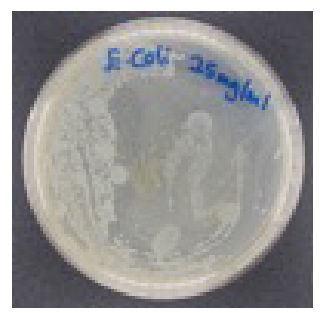

Positive
12.5

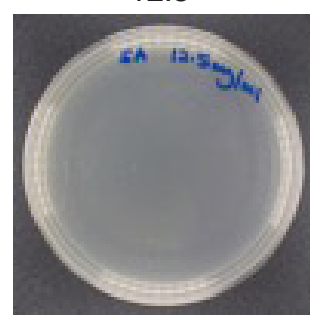

Negative

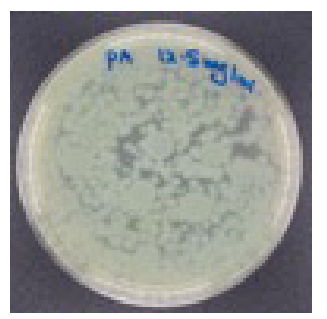

Positive

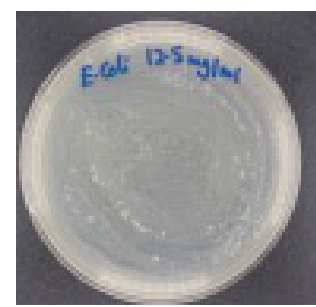

Positive
6.25

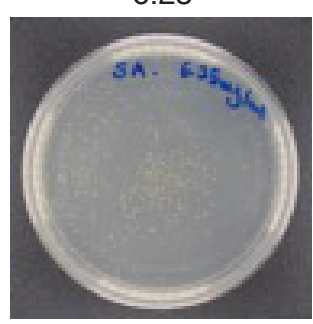

Positive

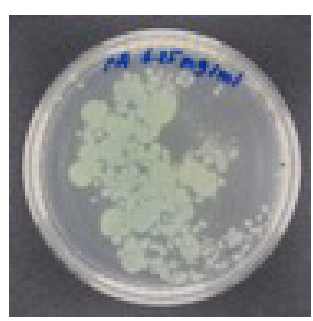

Positive

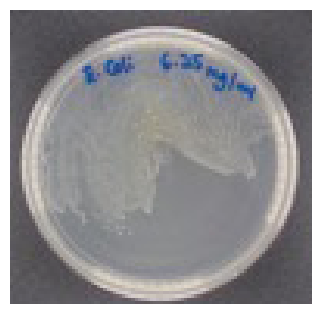

Positive

Note: *Negative - no bacterial growth; Positive - bacterial growth.

Figure 3. Minimum bactericidal concentration (MBC) of oil palm oil palm leaf extract (OPLE) against different organisms. 


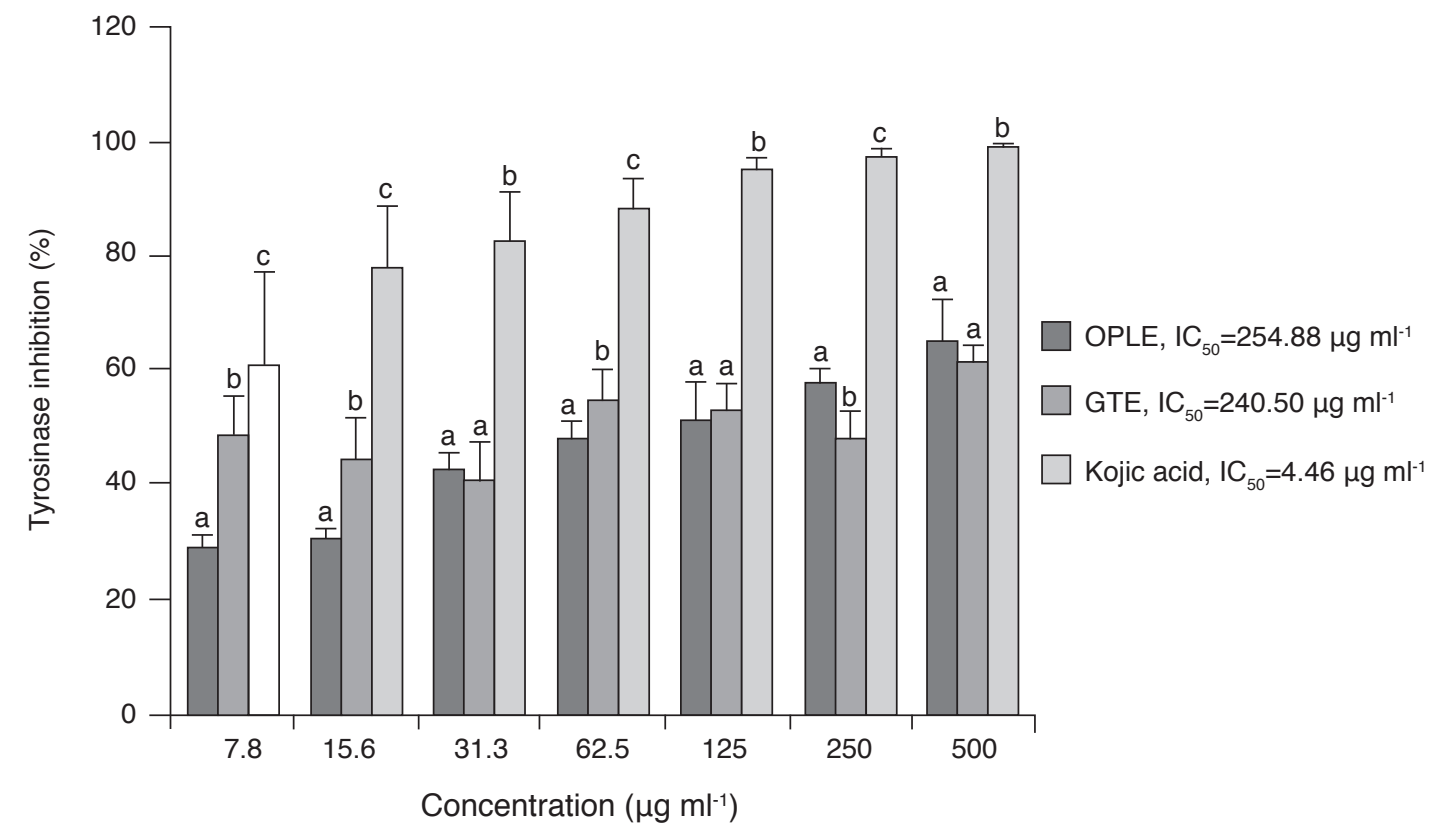

Note: GTE - green tea extract.

Figure 4. Anti-tyrosinase activity (\%) of oil palm leaf extract (OPLE) using mushroom tyrosinase against kojic acid, values with different superscript letters within the same concentration are statistically different $(p<0.05)$.

higher total polyphenols content than GTE and contain epigallocatechin, catechin, epicatechin, epigallocatechin gallate and epicatechin gallate (Mohamed, 2014).

In this study, the tyrosinase inhibition effect of OPLE and GTE might be due to the presence of the catechin group whereby Sato and Toriyama (2009) reported that catechin group inhibited melanin synthesis in B16 melanoma cells. Besides the catechin group, the presence of gallic acid in OPLE might also contribute to anti-tyrosinase activity. Gallic acid significantly inhibited both melanin synthesis and tyrosinase activity (Su et al., 2013). Kojic acid as a stronger inhibitor exhibited the lowest $\mathrm{IC}_{50}$ $4.46 \mu \mathrm{g} \mathrm{ml}^{-1}$, whereby OPLE and GTE exhibited a comparable $\mathrm{IC}_{50}$ value of 254.88 and $240.50 \mu \mathrm{g} \mathrm{ml}^{-1}$, respectively. The result suggested that OPLE has the potential to be used as natural skin lightening agent in topical applications.

\section{In vitro SPF}

The in vitro SPF determination is an indicator of protection against UVB radiation (290-320 nm), while UVA/UVB ratio measures the protection against UVA radiation (320-400 nm). OPLE which is a waxy paste with dark green colour was mixed with glycerine at $1 \%, 5 \%$ and $10 \%$ concentrations. Table 4 shows the results of mean SPF, UVA/UVB ratio and Boots Star Rating for glycerine and glycerine containing OPLE at $1 \%, 5 \%$ and $10 \%$. For a comparison, similar commercial GTE used in anti-tyrosinase activity were tested at same concentrations as OPLE. The test results show that glycerine has mean SPF of 0.99 and very low UVA/UVB ratio. However, the increment of OPLE in glycerine gradually decreased the percentage of transmittance where $1 \%$ OPLE recorded a transmittance at $104.09 \%, 5 \%$ OPLE at $66.92 \%$ transmittance and 10\% OPLE at $52.62 \%$ (Figure 5). The reduction in transmission profiles indicated an UVB absorbance by OPLE and thus showed an increment in SPF value (Table 4). There were no significant differences in percentage of transmittance and SPF values for glycerine containing GTE at 1\%, 5\% and 10\%. Besides SPF, increasing concentration of OPLE also increased the UVA/UVB ratio where 5\% and 10\% OPLE were categorised as having superior protection against UVA radiation and the results were similar to GTE. OPLE shows potentially good UV absorbance at UVB and UVA range wavelength. Therefore, OPLE showed a good potential to be used as natural sunscreen agent for topical application.

\section{CONCLUSION}

The oil palm leaves are abundant, under-utilised and one of the by-products of the palm oil industry. Based on these findings, OPLE shows antioxidant activity and anti-microbial effect towards gram positive bacteria. OPLE also provides good protection against UVA and UVB irradiation and has the potential to be used as skin lightening agent through inhibition 
TABLE 4. MEAN SPF, UVA/UVB RATIO OF GLYCERINE, 1\%, 5\% AND 10\% OPLE AND COMMERCIAL GREEN TEA EXTRACT IN GLYCERINE

\begin{tabular}{lcccc}
\hline \multicolumn{1}{c}{ Samples } & UVB protection & & \multicolumn{2}{c}{ UVA protection } \\
\cline { 2 - 2 } \cline { 5 - 5 } & $\begin{array}{c}\text { Mean SPF } \\
\text { (mean } \pm \text { std. dev) }\end{array}$ & & UVA/UVB ratio & Category \\
\hline Glycerine & $0.99 \pm 0.01$ & 0.076 & Too low/no claim \\
Glycerine $+1 \%$ OPLE & $0.96 \pm 0.01$ & & 0.645 & Good \\
Glycerine $+5 \%$ OPLE & $1.48 \pm 0.01$ & & 0.906 & Superior \\
Glycerine $+10 \%$ OPLE & $1.87 \pm 0.01$ & & 0.910 & Superior \\
Glycerine $+1 \%$ GTE & $1.01 \pm 0.01$ & & 0.634 & Good \\
Glycerine $+5 \%$ GTE & $0.98 \pm 0.01$ & & 1.040 & Ultra \\
Glycerine $+10 \%$ GTE & $1.00 \pm 0.01$ & & 1.278 & Ultra \\
\hline
\end{tabular}

Note: *GTE - commercial green tea extract. UV - ultraviolet. $\mathrm{SPF}$ - sun protection factor.

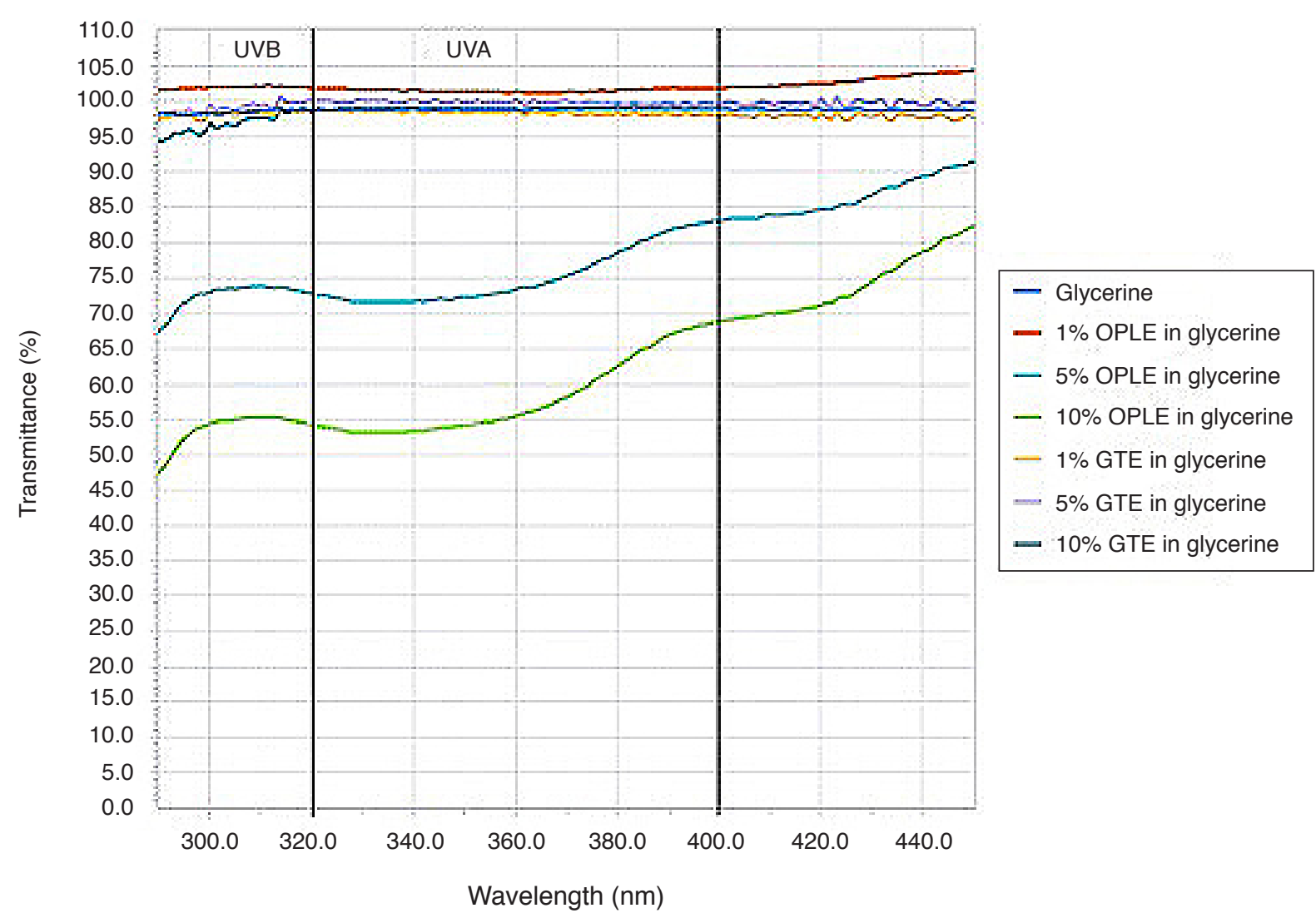

Figure 5. Transmittance profile of different concentrations of oil palm leaf extract (OPLE) and commercial green tea extract (GTE) in glycerine.

of tyrosinase enzyme. Therefore, OPLE can be further developed in topical applications as natural sunscreen and skin lightening agent.

\section{ACKNOWLEDGEMENT}

The authors wish to thank the Director-General of MPOB for permission to publish this article. The authors also gratefully acknowledged staff of the Consumer Product Development Unit, MPOB for their technical support.

\section{REFERENCES}

ABDULLAH, N and SULAIMAN, F (2013). Chapter 3: The oil palm wastes in Malaysia. Biomass Now - Sustainable Growth and Use (Matovic, M D ed.). DOI: 10.5772/55302. http: / / www.intechopen.com/ books / biomass-now-sustainable-growth-and-use / the-oil-palm-wastes-in-malaysia

ANDERSON, M W; HEWITT, J P and SPRUCE, S R (1997). Broad spectrum physical sunscreens: titanium dioxide and zinc oxide. Sunscreens (Love, 
N J; Shaath, N A and Pathak, M A eds.). Marcel and Dekker, Cosmetic Science and Technology Series, New York. p. 353-398.

ANITHA, T (2012). Medicinal plants used in skin protection. Asian J Phar Clin Res, 5(3): 35-38.

BASIRON, Y and CHAN, K W (2004). The oil palm and its sustainability. J. Oil Palm Res. Vol. 16: 1-10.

BLOIS, M S (1958). Antioxidant determinations by the use of a stable free radical. Nature, 29: 1199-1200.

BOOTS THE CHEMIST LTD (1992). The Guide to Practical Measurement of UVA/UVB Ratios. The Boots Co. PLC, Nottingham, England.

CHONG, K H; ZURAINI, Z; SASIDHARAN, S; KALNISHA DEVI, P V; YOGA LATHA, L and RAMANATHAN, $S$ (2008). Antimicrobial activity of Elaeis guineensis leaf. Pharmacologyonline, 3: 379-386.

CHIARI, M; JORAY, M B; RUIZ, G; PALACIOS, S M and CARPINELLA, M C (2010). Tyrosinase inhibitory activity of native plants from Central Argentina: isolation of an active principle from Lithraea molleoides. Food Chem, 120(1): 10-14.

COLLARIS, E J and FRANK, J (2008). Photoallergic contact dermatitis caused by ultraviolet filters in different sunscreens. Int. J. Dermatol., 47: 35-37.

COLIPA (2006). Standardisation Mandate Assigned to CEN Concerning Methods for Testing Efficacy of Sunscreen Products. European Commission, Brussels. p. 1-78. http://ec.europa.eu/growth/toolsdatabases $/$ mandates $/$ index.cfm?fuseaction $=$ search. detail\&id=346, accessed in March 2016.

COLIPA (2011). In vitro Method for the Determination of the UVA Protection Factor and "Critical Wavelength" Values of Sunscreen Products Guideline. p. 1-28.

DIFFEY, B L (1994). A method for broad spectrum classification of sunscreens. Int. J. Cosmet. Sci., 16: 47-52.

DIFFEY, B L and ROBSON, J (1989). A new substrate to measure sunscreen protection factors throughout the ultraviolet spectrum. J. Soc. Cosmet. Chem., 40: 127-133.

DUPONT, E; GOMEZ, J and BILODEAU, D (2013). Beyond UV radiation: a skin under challenge. Int. J. Cosmet. Sci., 35: 224-232.

ELOFF, J N (1998). A sensitive and quick microplate method to determine the minimal inhibitory concentration of plant extracts for bacteria. Plant Medica, 64: 711-713.
GILLBRO, J M and OLSSON, M J (2011). The melanogenesis and mechanisms of skin-lightening agents-existing and new approaches. Int. J. Cosmet. Sci., 33(3): 210-221.

GOSWAMI, P K; SAMANT, M and SRIVASTAVA, R (2013). Natural sunscreen agents: a review. Sch. Acad. J. Pharm., 2(6): 458-463.

HEARING, V J and TSUKAMOTO, K (1991). Enzymatic control of pigmentation in mammals. FASEB J., 5(14): 2902-2909.

ISO (2004). ISO 24444:2010. Cosmetics-sun protection test methods-in vivo determination of the sun protection factor (SPF). https: / / www.evs. ee/products/iso-24444-2010, accessed in February 2016.

JAFFRI, J M; MOHAMED, S; ROHIMI, N; AHMAD, I N; NOORDIN, M M and MANAP, Y A (2011). Antihypertensive and cardiovascular effects of catechin-rich oil palm (Elaeis guineensis) leaf extract in nitric oxide-deficient rats. J Med Food, 14 (7/8): 775-783.

JO, Y H; YUK, H G; LEE, J W; KIM, J C; KIM, R and LEE, S C (2012). Antioxidant, tyrosinase inhibitory, and acetylcholinesterase inhibitory activities of green tea (Camellia sinensis L.) seed and its pericarp. Food Sci. Biotechnol., 21(3): 761-768.

JURD, L; KING, A D Jr; MIHARA, K and STANLEY, W L (1971). Antimicrobial properties of natural phenols and related compounds. J Appl Microbiol, (3): 507-510.

KORAC, R R and KHAMBHOLJA, K M (2011). Potential of herbs in skin protection from ultraviolet radiation. Phcog Rev., 5(10): 164-173.

MACHEIX, J J; FLEURIET, A and BILLOT, J (1990). Fruit Phenolics. CRC Press, Inc., Boca Raton.

MARIA, P; EDOARDO, Z; PIERGIORGIO, N; ANDREA, P; DENIS, G and MAURO, A (2012). In vitro evaluation of sunscreens: an update for the clinicians. International Scholarly Research Network. ISRN Dermatology Vol. 2012: 1-4.

MOHAMED, S (2014). Oil palm leaf: a new functional food ingredient for health and disease prevention. J Food Process Technol., 5 (2): 1-6.

MPOB (2015). Overview of the Malaysian oil palm industry. Economics \& Industry Development Division, Malaysian Palm Oil Board. http://bepi. mpob.gov.my, accessed on 18 April 2016. 
NG, M H and CHOO, Y M (2010). Determination of antioxidants in oil palm leaves (Elaeis guineensis). Am. J. Applied Sci., 7(9): 1243-1247.

NG, S Y; ABDULLAH, S and CHONG, K P (2013). Phytochemical constituents from leaves of Elaeis guineensis and their antioxidant and antimicrobial activities. Int J Pharm Pharm Sci., 5 (4): 137-140.

NO, J K; SOUNG, D Y; KIM, Y J; JUN, Y S; RHEE, S H; YOKOZAWA, T and CHUNG, H Y (1999). Inhibition of tyrosinase by green tea components. Life Sci., 65(21): 241-246.

PHANG, N L; ABDUL KHALID, M F Y; LIM, C K; HAMBALI, $S$ A; SHARIFF, $S$ and THURAISNGAM, $S$ (2009). Extract from oil palm leaves comprising phenolic acids. Patent WO 2009110782 A1.

PRIOR, R L; WU XIANLI and SCHAICH, K (2005). Standardized method for determination of antioxidant capacity and phenolic in food and dietary supplement, J. Agric. Food Chem., 53: 42904302.

RUNNIE, I; MOHAMED MUSTAPHA, N; MUSEC, R; HAMID, A; NAWAWID, H; ABERWARDENAE, M Y and MOHAMED, S (2003). Antioxidant and hypocholesterolemic effects of Elaeis guineesis frond extract on hypercholesterolemic rabbits. ASEAN Food J., 12(3): 137-148.

SATO, K and TORIYAMA, M (2009). Depigmenting effect of catechins. Molecules, 14: 4425-4432.

SINGLETON, V R; ORTHIFER, R and LAMUELARAVENTOS, R M (1999). Analysis of total phenols and other oxidation substrates and antioxidants by means of Folin-Ciocalteu reagent. Methods in Enzymology, 299: 152-178.

SU, T R; LIN, J J; TSAI, C C; HUANG, T K; YANG, Z Y; WU, M O; ZHENG, Y Q; SU, C C and WU, Y $\mathrm{J}$ (2013). Inhibition of melanogenesis by gallic acid: possible involvement of the PI3K/Akt, MEK/ERK and Wnt $/ \beta$-catenin signalling pathways in B16F10 cells. Int J Mol Sci., 14(10): 20443-20458.

UNITED STATES ENVIRONMENTAL PROTECTION AGENCY (2010). Health effects of overexposure to sun. www.epa.gov/ozone/ strathome.html

VIJAYARATHNA, S and SASIDHARAN, S (2012). Antioxidant activity of Elaeis guineensis leaf extract: an alternative nutraceutical approach in impeding aging. APCBEE Procedia, 2: 153-159.

VIJAYARATHNA, S; ZAKARIA, Z; CHEN, Y; YOGA LATHA, L; KANWAR, J R and SASIDHARAN, S (2012). The antimicrobial efficacy of Elaeis guineensis: characterization, in vitro and in vivo studies. Molecules, 17: 4860-4877.

WAN ZAHARI, M; ABU HASSAN, O; WONG, H $\mathrm{K}$ and LIANG, J B (2002). Utilization of oil palm frond-based diets for beef and dairy production in Malaysia. International Symposium on Recent Advances in Animal Nutrition, 22, September 2002, New Delhi, India. Accessed on 17 February 2016.

WAN ZAHARI, $M$ and MOHD FARID, M (2011). Oil-palm by-products as feeds for livestock in Malaysia. PIPOC 2011 International Palm Oil Congress. http:/ / umkeprints.umk.edu.my / 1147/, accessed on 17 February 2016. 